\title{
Identification of Aluminum Responsive Genes in Al-Tolerant Soybean Line PI 416937
}

\author{
Dechassa Duressa, ${ }^{1}$ Khairy Soliman, ${ }^{1}$ and Dongquan Chen $^{2,3}$ \\ ${ }^{1}$ Department of Natural Resources and Environmental Sciences, Alabama A\&M University, Normal, AL 35762, USA \\ ${ }^{2}$ Biostatistics and Bioinformatics Unit, Comprehensive Cancer Center, Division of Preventive Medicine, \\ Department of Medicine, The University of Alabama at Birmingham, Birmingham, AL 35294-3300, USA \\ ${ }^{3}$ School of Medicine, Clinical and Translational Institute, West Virginia University, HSC-RM-5523, Morgantown, \\ WV 26506-9161, USA
}

Correspondence should be addressed to Dechassa Duressa, dech_1@yahoo.com

Received 20 April 2010; Revised 16 July 2010; Accepted 7 August 2010

Academic Editor: Akhilesh Kumar Tyagi

Copyright ( 2010 Dechassa Duressa et al. This is an open access article distributed under the Creative Commons Attribution License, which permits unrestricted use, distribution, and reproduction in any medium, provided the original work is properly cited.

\begin{abstract}
Soybean is one of the most aluminum (Al) sensitive plants. The complex inheritance of Al tolerance trait has so far undermined breeding efforts to develop Al-tolerant soybeans. Discovering the genetic factors underlying the Al tolerance mechanisms would undoubtedly accelerate the pace of such endeavor. As a first step toward this goal, we analyzed the transcriptome profile in roots of Al-tolerant soybean line PI 416937 comparing Al-treated and untreated control plants using DNA microarrays. Many genes involved in transcription activation, stress response, cell metabolism and signaling were differentially expressed. Patterns of gene expression and mechanisms of Al toxicity and tolerance suggest that Cys2His2 and ADR6 transcription activators, cell wall modifying enzymes, and phytosulfokines growth factor play role in soybean $\mathrm{Al}$ tolerance. Our data provide insights into the molecular mechanisms of soybean $\mathrm{Al}$ tolerance and will have practical value in genetic improvement of $\mathrm{Al}$ tolerance trait.
\end{abstract}

\section{Introduction}

Aluminum $(\mathrm{Al})$ toxicity is a major constraint of crop production on acid soils. In view of the fact that $40 \%$ of world's arable land is acidic [1,2], Al toxicity remains a major hurdle for increasing world food, fiber, and fuel production particularly via expansion of cultivation into acid soils.

Aluminum inflicts a wide range of cellular injuries in plants that ultimately result in reduced root growth, nutrient and water uptake, and productivity $[1,2]$. Plants possess some degree of tolerance to $\mathrm{Al}$ toxicity that varies among species and genotypes [1,3-6]. Al tolerance mechanisms include exclusion and internal detoxification. Al exclusion via rhizosphere Al-organic acid anion complex formation is the most widely documented physiological mechanism of $\mathrm{Al}$ tolerance in cultivated and wild plants alike $[1,7]$. Root-exuded citrate, malate, and oxalate are the key organic acid anions involved in such mechanism. Genes involved in Al-induced root exudation of malate and citrate have been cloned in wheat [8] and sorghum [5], and their variants are being discovered in several plant species. Internal detoxification mechanisms involve the formation of $\mathrm{Al}$ complexes with organic acids, acidic polypeptides, and/or proteins and subsequent sequestration of $\mathrm{Al}$ in organelles away from sensitive sites in the cell $[9,10]$. The genetic components of the internal detoxification pathways are yet to be elucidated.

In soybean, $\mathrm{Al}$ tolerance is a complex trait perhaps involving several genes and pathways $[11,12]$. Quantitative trait loci (QTL) mapping in a population derived from $\mathrm{Al}$ tolerant PI 416937 and $\mathrm{Al}$ sensitive Young has revealed five DNA markers associated with Al tolerance [11]. Most of the alleles were derived from Al-tolerant PI 416937. Other reported soybean Al tolerance genes include phosphoenolpyruvate carboxylase (PEPC), homolog of translationally controlled tumor proteins (TCTPs), inosine 5 '-monophosphate dehydrogenases (IMPDHs) [13], aluminum-induced 3-2 (Sali32), and aluminum-induced 5-4a (Sali 4-5a) [14]. Ermolayev 
et al. [13] and Ragland and Soliman [14] used gene expression as a tool to identify the above genes but the techniques used in these experiments were not sensitive enough to detect large number of genes that might be expected from the quantitative nature of soybean $\mathrm{Al}$ tolerance trait. The objective of this study was to discover putative $\mathrm{Al}$ tolerance genes in $\mathrm{Al}$ tolerant soybean line PI 416937 using DNA microarrays-a robust genome-wide transcript profiling technology. Such an approach was recently employed in wheat $[15,16]$, maize [17], Arabidopsis [18], and Medicago truncatula [19, 20] to discern the molecular basis of $\mathrm{Al}$ tolerance in the respective species.

\section{Materials and Methods}

2.1. Plant Genotype and Growth Conditions. An Al-tolerant soybean plant introduction (PI 416937) highly characterized for $\mathrm{Al}$ response $[12,21]$ was used in this experiment. Seeds were surface sterilized with $20 \%$ household bleach (Clorox) in water for $12 \mathrm{~min}$, rinsed with distilled-deionized water several times, and were germinated in deionized water moistened standard germination paper at $25^{\circ} \mathrm{C}$ in an incubator for $72 \mathrm{~h}$. Seedlings uniform in tap root length were transferred to black-painted pots filled with approximately $4 \mathrm{~L}$ of $800 \mu \mathrm{M} \mathrm{CaCl}_{2}$ background solution with $10 \mu \mathrm{M} \mathrm{Al}$ added (treated) or no $\mathrm{Al}$ added (control) in a Conviron growth chamber $(16 / 8 \mathrm{~h}$ light/ dark cycle with respective temp. of $28^{\circ} \mathrm{C} / 20^{\circ} \mathrm{C}$, photosynthetic photon density of $\left.100 \mu \mathrm{mol} \mathrm{m} \mathrm{m}^{-2} \mathrm{~s}^{-1}\right)$. The $\mathrm{pH}$ of the culture solution was adjusted to 4.3 and maintained at that level for the entire duration of the experiment. After 2, 12, 48, or $72 \mathrm{~h}$ of Al treatment $1 \mathrm{~cm}$ sections of the primary root tips of approximately 15 plants/pot were harvested, immediately flash frozen in liquid nitrogen, and stored at $-70^{\circ} \mathrm{C}$ for RNA extraction. Three independent replicates were used per treatment.

2.2. RNA Extraction, Microarray Procedure, and Data Analysis. Total RNA was extracted from $100 \mathrm{mg}$ root tissue samples using Qiagen RNeasy plant RNA isolation kit following the manufacturer's protocol (Qiagen, Inc.). The Affymetrix GeneChip Soybean Genome Array with over 68 000 probe sets, Glycine max L. and wild soybean combined, was used for microarray analysis of the soybean genome for $\mathrm{Al}$ tolerance. Three chips were used per treatment. Detailed procedures for RNA labeling and array analysis are described in the Manufacturer's GeneChip Expression Technical Manual (Affymetrix). Briefly, the quality of total RNA was determined using the RNA 6000 Nano Chip on Agilent BioAnalyzer 2100 prior to double-stranded cDNA synthesis. Total RNA in the amount of $2 \mu \mathrm{g}$ was used for double-stranded cDNA generation by linear amplification using oligo dT-T7 primer and reverse transcriptase (RT). Subsequently, biotin-labeled cRNA was synthesized by in vitro transcription (IVT) using the ENZO High Yield IVT kit (ENZO). Quality and quantity of cRNA were assessed using the RNA 6000 Nano chip on Agilent BioAnalyzer 2100. Fifteen-microgram cRNA was used for hybridization.
Arrays were hybridized overnight at $45^{\circ} \mathrm{C}$ for $16 \mathrm{~h}$ in GeneArray Hybridization Oven 640 (Affymetrix). The next day, arrays were washed and stained in the Fluidics Station 450 (Affymetrix) and scanned by the High Resolution GeneChip Scanner 3000 (Affymetrix).

Gene expression values were determined using theGeneChip Operating Software (GCOS 1.1, Affymetrix). The expression levels were subjected to data query and data mining in Data Mining Tool (DMT). Statistical Analysis of the data was conducted using the software packages ArrayAssist Enterprise together with Pathway Assist (Stratagene/Agilent, Santa Clara, CA). The raw GeneChip files from GeneChip Operating Software (GCOS, Affymetrix, CA) were uploaded, background-subtracted, variance stabilized, and normalized with GC-RMA method [22]. The control group was used as a baseline to calculate the intensity ratio/fold changes of the treatment versus control. The ratio was $\log _{2}$-transformed before further statistical analysis. The $P$ values were obtained by an unpaired $t$-test assuming unequal variance. Significantly upregulated and downregulated genes were annotated using protein databases accessed by blastx at National Center for Biotechnology Information (NCBI).

2.3. Quantitative Real-Time PCR. Quantitative real-time PCR quantification of transcript levels for representative genes [Gma. 20326: F-5' -tcactccccaccttatcgag-3', R-5' -tcatgtggtggagtgtggtt-3'; Gma. 6948: F-5' -ttatctccggcgaaaacctc$3^{\prime}$, R-5' -tcgtggtgcagcagtttaag-3'; Gma.12326: F-5' -agccactcaaatggttcagc- $3^{\prime}, \mathrm{R}-5^{\prime}$-tctccttgtccttctccttcc-3'; Gma. 24062: F-5' -tgccgaaggatcatctcaac- $3^{\prime}$, R-5' -cgagggataatggttgatgg- $3^{\prime}$; Gma.26937: F-5' -tacccaaaaggcaggcatac-3', R-5' -ggccgaggtacaaacacatc-3'; Gma.4156: F-5' -tccaatgctgacaagtgctc-3', R$5^{\prime}$-tagggacactccgtccaatc-3'; Gma.2577: F-5'-acgcctatgaacgtgaaacc-3', R-5'-aacatcagcggagagcattc-3'] from microarray experiments was conducted using the Roche Diagnostics light Cycler 480 System with SYBR green detection (Roche Diagnostic, Corp) using beta-tubulin gene (beta-tubulin: R-5' -CCATCAAACCTCAAGGAAGC-3', F-5' -TGCTGTCCTCTTGGACAATG- $3^{\prime}$ ) as internal control. mRNA was isolated from plants grown under similar experimental conditions as in the microarray experiments. mRNA extraction and quality test was as described above. RNA samples were treated with Applied Biosystems Turbo DNA-free DNase (Ambion, Inc.) to remove DNA contamination. Briefly, $2 \mu \mathrm{l} 10 \mathrm{x}$ DNase I buffer and $1 \mu \mathrm{l}$ rDNase I were added to $20 \mu \mathrm{l}$ RNA sample, and the mix was incubated at $37^{\circ} \mathrm{C}$ for 30 minutes in water bath. Subsequently, $2 \mu \mathrm{l}$ resuspended DNase inactivation reagent was added and the samples mixed well and incubated at room temperature for 3 minutes. Samples were then centrifuged at $10000 \mathrm{~g}$ for $1.5 \mathrm{~min}$ (Eppendorf centrifuge $5415 \mathrm{D}$ ) in $1.6 \mathrm{ml}$ centrifuge tubes and supernatants transferred to fresh tubes.

cDNA was synthesized from $1 \mu \mathrm{g}$ DNase-treated RNA samples using the Roche Diagnostics Transcriptor First Strand cDNA Synthesis Kit (Roche Diagnostics, Corp) according to manufacturer's protocol. cDNA concentration and quality was determined using NanoDrop Spectrophotometer brand ND-1000 (NanoDrop Technologies, Inc.). cDNA samples were diluted with nuclease-free water in 


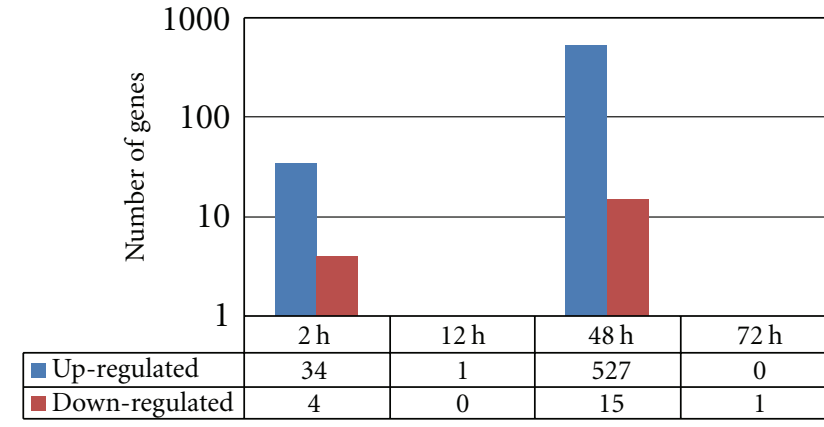

FIGURE 1: Number of Al upregulated and downregulated genes in soybean genotype PI 416937 in a time-course experiment.

varying ratios ranging from $1: 4$ to $1: 10$ depending on sample concentration. A total reaction volume of $11 \mu \mathrm{l}$ comprising $2 \mu \mathrm{l} \mathrm{cDNA}$ sample, $2 \mu \mathrm{l}$ each of the reverse and forward primers at $0.2 \mu \mathrm{M}$ concentration, and $5 \mu \mathrm{l} \mathrm{SYBR}$ mix was prepared in 96-well plates (Roche Diagnostics) in two biological and three technical replicates for each gene. A real-time PCR profile of preincubation at $95^{\circ} \mathrm{C}$ for $5 \mathrm{~min}$, a 45-cycle amplification at $95^{\circ} \mathrm{C}$ for 10 second, $55^{\circ} \mathrm{C}$ for 20 second, and $72^{\circ} \mathrm{C}$ for 20 second, melting at $95^{\circ} \mathrm{C}$ for $1 \mathrm{~min}$, $65^{\circ} \mathrm{C}$ for $1 \mathrm{~min}$, and $95^{\circ} \mathrm{C}$ continuous, and cooling at $40^{\circ} \mathrm{C}$ for 30 seconds was used to amplify the samples. Negative controls in which cDNA sample was replaced with PCR grade water for each primer pair were included in each run. Sample wells were individually assessed for data quality by evaluating amplification curves and PCR product specificity was verified by melting curve analysis. The expression level of target genes was normalized using in-run beta-tubulin gene as internal control, and transcript concentration ratios were calculated using the $\Delta \Delta \mathrm{C}_{T}$-Method [23]. The change in gene expression levels (fold change) was calculated as treatment to control ratio and compared with results from microarray.

\section{Results and Discussion}

3.1. Gene Expression in Response to 2-Hour Al Treatment. A total of 38 genes were identified as differentially expressed in the $10 \mu \mathrm{M}$ Al-treated experimental plants compared to no $\mathrm{Al}$ added controls at $2 \mathrm{~h}$ post Al treatment (Figure 1). Thirtyfour of them were upregulated and 4 were downregulated with a fold change ranging from 3.08 to 32.55 (Table 1).

3.2. Gene Expression in Response to 12- and 72-Hour Al Treatment. At 12 and $72 \mathrm{~h}$ post treatment only one gene each showed significant change in expression in response to $\mathrm{Al}$ treatment (Figure 1 and Table 1).

3.3. Gene Expression in Response to 48-Hour Al Treatment. The highest number of differentially expressed genes was detected at $48 \mathrm{~h}$ post $\mathrm{Al}$ treatment (Figures 1 and 2). A total of 542 genes ( $97.2 \%$ upregulated and $2.8 \%$ downregulated) were detected. Those exceeding 13 -fold changes are presented in Table 2. The marked fold differences observed in the current research are substantially higher in comparison

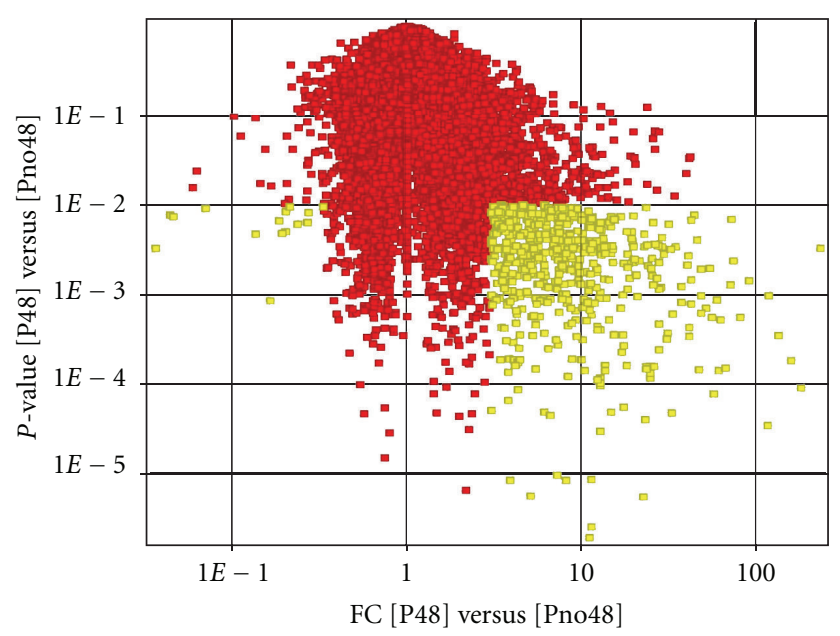

Figure 2: Distribution of $P$-value and fold change for gene expression profile of soybean genotype PI $41693748 \mathrm{~h}$ post treatment. Yellow squares are aluminum regulated genes. Red squares are genes with above back ground expression level. FC, fold change; [P48] versus [Pno48], $48 \mathrm{~h}$ treated versus control comparison. $P$-value: the probability that the observed results are obtained by chance not due to $\mathrm{Al}$ effect.

with results obtained by most authors but are comparable to results of $[18,24]$. There were two genes in common between the set of genes detected at $2 \mathrm{~h}$ and $48 \mathrm{~h}$ post treatment (Gma.2577, 7-fold downregulated at $2 \mathrm{~h}$ and 8-fold upregulated at $48 \mathrm{~h}$ and Gma.26937, 8-fold downregulated at $2 \mathrm{~h}$ and 115 upregulated at $48 \mathrm{~h}$ ). Similar patterns of gene expression were observed in Arabidopsis roots under $\mathrm{Al}$ stress with few overlaps between sets of genes detected at $6 \mathrm{~h}$ and $48 \mathrm{~h}$ post $\mathrm{Al}$ treatment [18].

The temporal pattern of $\mathrm{Al}$-induced gene expression changes observed in this study diverges from results of other authors. At 12 and $72 \mathrm{~h}$, almost no genes were differentially expressed or detected. The virtually no detection of Alregulated genes at 12 and $72 \mathrm{~h}$ post treatment seems a little odd but it is what is expressed in this soybean genotype at detection thresholds of $P$-value $<.01$ and 3 -fold change in an experiment with 3 replications. Gene expression is species and genotype specific [15-20] making comparison of results across different studies difficult. The most likely explanation for the 72-hour result is that $\mathrm{Al}$ toxicity could have already been neutralized by the $72 \mathrm{~h}$, making differential gene expression unnecessary. The lack of transcriptional response at $12 \mathrm{~h}$, however, is a biological puzzle, and it could represent a very unusual temporal transcriptome response of this soybean genotype to $\mathrm{Al}$ stress. Among the few reported Al microarray studies, the results of Kumari et al. [18] in Arabidopsis is the closest to ours with regard to the number of genes detected at early and late time points. They detected 127 genes at $6 \mathrm{~h}$ post treatment and 733 genes at $48 \mathrm{~h}$ post treatment using a threshold of a 2 -fold change whereas we detected 38 genes at $2 \mathrm{~h}$ and 542 at $48 \mathrm{~h}$ using a 3 -fold change.

All of the differentially expressed genes that were functionally annotated by the Genbank nonredundant protein database were grouped into five functional categories based 


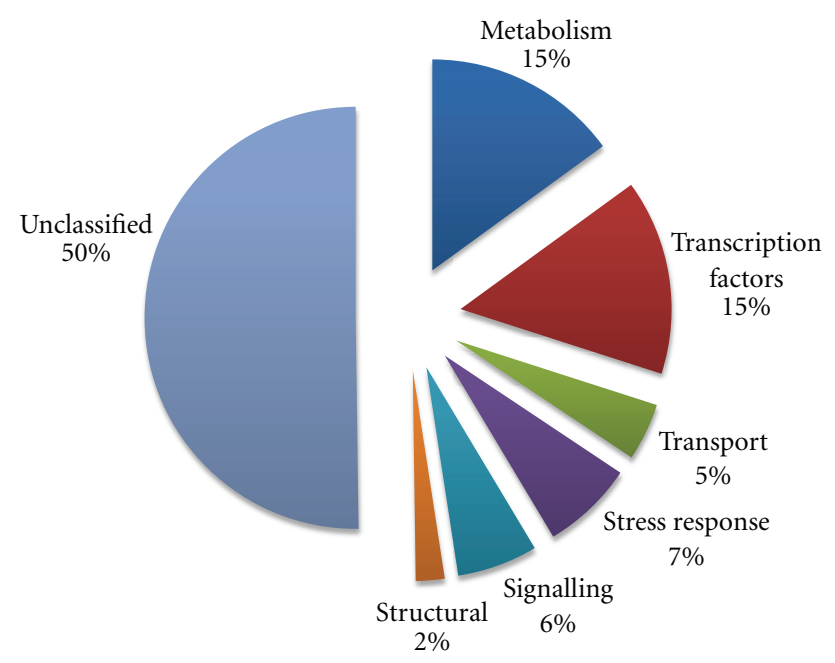

FIGURE 3: Functional classifications of genes differentially regulated by aluminum in soybean genotype PI 416937.

on their putative cellular function. The functional classification showed that stress- and metabolism-related genes constitute the major fractions of Al-regulated genes (Figure 3).

3.4. Quantitative Real-Time PCR Validation of Microarray Expression Levels. The microarray gene expression levels were validated with quantitative real-time PCR for representative genes (Figure 4). In general, the microarray results were in agreement with $q R T-P C R$ but in a few cases quantitative $R T-P C R$ gave higher levels of expression compared to microarray. Such results are obtained by a number of investigators $[16,20,25]$. Detail discussion of factors contributing to the discrepancy between microarray and $R T$ $P C R$ gene expression levels is covered in [26]. Many authors attribute the phenomenon to the high dynamic range and greater sensitivity of PCR detection. It is worth noting that the gene expression kinetics depicted in Figure 1 shows the efficacy of our experimental design in capturing the full dynamic range of gene expression profiles in the soybean genotype studied. Gene expression peaks at 2 and $48 \mathrm{~h}$ suggesting that major savings in microarray experimental expenditure could be realized by limiting sampling to these time points in future experiments.

\subsection{Differentially Regulated Genes by Functional Category}

3.5.1. Genes Related to Transcription Factors. A number of transcription factors including $b Z I P$, WRKY, MYB, ADR6, and NAc were highly upregulated in the present study (Tables 1 and 2). Members of these families of transcription factors were previously detected under $\mathrm{Al}$ stress in several plant species $[16,18-20,27]$. Cys2His2-type zinc finger (bZIP) and auxin downregulated (ADR6) factors are particularly interesting from Al tolerance perspective. Cys2His2-type zinc finger $(b Z I P)$ protein coregulates molecular response to proton and $\mathrm{Al}$ toxicities [28]. It controls the expression of AlMT1-a malate transporter protein that acts in $\mathrm{Al}$

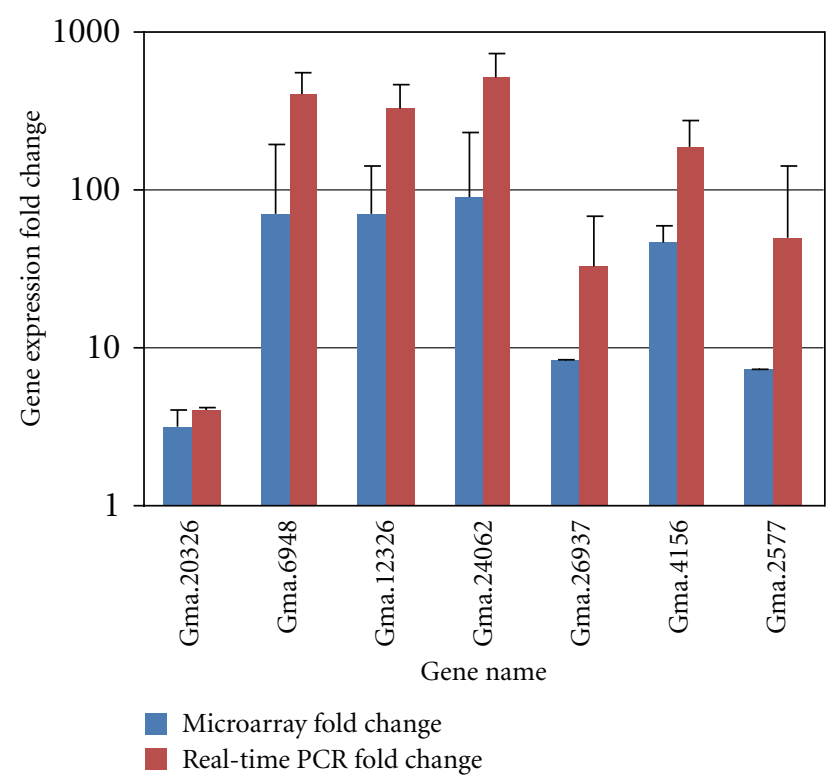

FIGURE 4: RT-PCR gene expression values for representative genes and its correlation with microarray data. Genes were selected to represent the range of expression levels observed in microarray data. Gene expression fold change: ratio of gene expression of Al-treated plants to untreated controls. Data presented are mean \pm SE.

exclusion mechanism. In this study, Cys2His2 (Gma.4526, Table 2) was upregulated 51 -fold at $48 \mathrm{~h}$ post treatment suggesting that malate plays a major role in $\mathrm{Al}$ tolerance mechanism of PI 416937 soybean. Earlier physiological study by Silva et al. [29] showed that $\mathrm{Al}$ stress increases exudation of both malate and citrate during the first $6 \mathrm{~h}$ of exposure to $\mathrm{Al}$ in both tolerant and sensitive soybean types. But they concluded that the sustained accumulation and exudation of citrate is mainly responsible for the genotypic differences in $\mathrm{Al}$ tolerance. In the present work, $48 \mathrm{~h}$ after $\mathrm{Al}$ exposure the malate transporter regulator protein was highly expressed in contrast with the observation of Silva et al. [29]. We postulate that Cys2His2 might regulate the expression of other $\mathrm{Al}$ tolerance genes in addition to malate transporter. It is also possible that malate biosynthesis becomes a limiting step or malate might indeed play a major role in soybean $\mathrm{Al}$ tolerance contrary to earlier conclusions. ADR6 transcription factors were previously reported as $\mathrm{Al}$ tolerance genes $[14,18]$. In the present study, ADR6 was highly upregulated (14-fold, Table 2). The plant hormone auxin and ADR6 exhibit opposite behavior in plant roots under $\mathrm{Al}$ stress. $\mathrm{Al}$ has been shown to inhibit auxin biosynthesis and transport genes as one possible mechanism of its toxicity [18]. On the contrary, ADR6 - an auxin downregulated transcription factor is induced under Al stress perhaps mimicking auxin's role of promoting root growth. These observations suggest that Cys2His2 and ADR6 transcription factors are important modulators of soybean molecular response to $\mathrm{Al}$ stress.

3.5.2. Genes Related to Transporters. Transporters, specifically malate (ALMTs) and citrate (MATE) transporters are the first $\mathrm{Al}$ tolerance genes cloned in plants and represent the 
TABLE 1: Aluminum-regulated genes in soybean genotype PI $4169372 \mathrm{~h}$ post aluminum treatment ${ }^{\dagger}$.

\begin{tabular}{|c|c|c|c|c|c|}
\hline Unigene ID & Fold change & Average \pm SD & Functional category & Annotation & $e$-value \\
\hline Gma.18664 & $32.55($ down $)$ & $-0.88 \pm 0.06$ & Stress response & $\begin{array}{l}\text { Anionic peroxidase/ } \\
\text { oxidative stress }\end{array}$ & $6 e-66$ \\
\hline Gma.4152 & 29.89 (up) & $4.39 \pm 0.13$ & Stress response & $\begin{array}{l}\text { Trypsin and protease } \\
\text { inhibitor }\end{array}$ & $2 e-20$ \\
\hline Gma.17961 & 29.13 (up) & $4.63 \pm 0.14$ & Stress response & $\begin{array}{l}\text { Soybean oleosin isoform } \\
\text { B }\end{array}$ & $2 e-22$ \\
\hline Gma.26984 & 27.751 (up) & $3.96 \pm 0.05$ & Stress response & $\begin{array}{l}\text { Putative protease } \\
\text { inhibitor }\end{array}$ & $4 e-35$ \\
\hline Gma15007 & 24.75 (up) & $3.77 \pm 0.24$ & Metabolism & Ferredoxin 2 protein & $2 e-46$ \\
\hline Gma.29855 & 11.98 (up) & $1.81 \pm 0.15$ & Metabolism & $\begin{array}{l}\text { Ribulose-1, } \\
\text { 5-bisphosphate } \\
\text { carboxylase }\end{array}$ & $5 e-100$ \\
\hline Gma.18110 & 11.36 (up) & $2.87 \pm 0.19$ & Unclassified & $\begin{array}{l}\text { Cp12-2 Protein/peptide } \\
\text { cross-linking }\end{array}$ & $9 e-29$ \\
\hline Gma.26937 & 8.29 (down) & $-0.61 \pm 0.03$ & Unclassified & Unknown & - \\
\hline Gma.10987 & 8.03 (up) & $2.76 \pm 0.09$ & Metabolism & $\begin{array}{l}\text { Ribulose bisphosphate } \\
\text { carboxylase }\end{array}$ & $1 e-33$ \\
\hline BE024005 & 7.58 (up) & $3.41 \pm 0.27$ & Stress response & $\begin{array}{l}\text { Glutaredoxin family } \\
\text { protein- } \\
\text { /glutathione-dependent } \\
\text { reductase }\end{array}$ & $6 e-24$ \\
\hline Gma.2577 & $7.3($ down $)$ & $-0.86 \pm 0.02$ & Metabolism & Hydrolase family protein & $7 e-30$ \\
\hline Gma.21354 & 6.51 (up) & $2.59 \pm 0.12$ & Transcription factor & $\begin{array}{l}\text { NAc1 domain protein } \\
\text { Plant development } \\
\text { protein }\end{array}$ & $1 e-61$ \\
\hline Gma.4156 & 6.41 (up) & $1.26 \pm 0.24$ & Transcription factor & $\begin{array}{l}\text { Zinc finger } \\
\text { protein/transcription } \\
\text { factor }(\mathrm{CCCH} \text {-type } \\
\text { family) }\end{array}$ & $4 e-10$ \\
\hline Gma.32658 & 5.78 (up) & $2.25 \pm 0.31$ & Unclassified & Hypothetical protein & $1 e-44$ \\
\hline Gma.12121 & 5.36 (up) & $2.23 \pm 0.07$ & Unclassified & Hypothetical protein & $9 e-13$ \\
\hline Gma.6487 & 4.62 (up) & $2.33 \pm 0.19$ & Unclassified & Unknown & - \\
\hline Gma.15538 & 4.47 (up) & $2.16 \pm 0.21$ & Stress response & $\begin{array}{l}\text { Glutaredoxin family } \\
\text { protein (arsenate } \\
\text { reductase) }\end{array}$ & $7 e-39$ \\
\hline Gma.28376 & 4.43 (down) & $-0.02 \pm 0.28$ & Stress response & $\begin{array}{l}\text { Syringolide-induced } \\
\text { protein B13-1-9 } \\
\text { hypersensitive response }\end{array}$ & $6 e-102$ \\
\hline Gma.12481 & 4.39 (up) & $2.52 \pm 0.19$ & Unclassified & Hypothetical protein & $2 e-44$ \\
\hline Gma.4226 & 4.36 (up) & $1.53 \pm 0.16$ & Stress response & $\begin{array}{l}\text { AТРP2-A13 } \\
\text { protein/wound response }\end{array}$ & $2 e-44$ \\
\hline Gma.1248 & 4.09 (up) & $2.50 \pm 0.16$ & Signaling & $\begin{array}{l}\text { nod33 protein (putative } \\
\text { phosphatase) }\end{array}$ & $6 e-88$ \\
\hline BQ629821 & 3.97 (up) & $2.01 \pm 0.17$ & Transcription factor & $\begin{array}{l}\text { My family transcription } \\
\text { factor }\end{array}$ & $5 e-14$ \\
\hline Gma.1043 & 3.86 (up) & $1.03 \pm 0.07$ & Unclassified & Hypothetical protein & $6 e-21$ \\
\hline Gma.31382 & 3.79 (up) & $2.04 \pm 0.07$ & Transcription factor & $\begin{array}{l}\text { Bzip transcription factor } \\
\text { (bzip 105) }\end{array}$ & 0.0 \\
\hline BQ785779 & 3.75 (up) & $1.68 \pm 0.13$ & Unclassified & Unknown & - \\
\hline Gma.4710 & 3.54 (up) & $1.63 \pm 0.21$ & Unclassified & Hypothetical protein & $3 e-19$ \\
\hline
\end{tabular}


TABLE 1: Continued.

\begin{tabular}{|c|c|c|c|c|c|}
\hline Unigene ID & Fold change & Average $\pm \mathrm{SD}$ & Functional category & Annotation & $e$-value \\
\hline Gma.27015 & 3.53 (up) & $1.67 \pm 0.08$ & Unclassified & $\begin{array}{l}\text { Octicosapeptide PB1 } \\
\text { domain protein }\end{array}$ & $2 e-34$ \\
\hline Gma.23849 & 3.51 (up) & $1.01 \pm 0.05$ & Unclassified & Unknown & - \\
\hline Gma.4216 & 3.39 (up) & $3.01 \pm 0.01$ & Metabolism & $\begin{array}{l}\text { Endo-xyloglucan } \\
\text { transferase/hydrolase }\end{array}$ & $3 e-64$ \\
\hline AW733463 & 3.38 (up) & $1.86 \pm 0.11$ & Unclassified & Unknown & - \\
\hline BF595565 & 3.35 (up) & $1.50 \pm 0.06$ & Metabolism & $\begin{array}{l}\text { SDP1 (sugar dependent } \\
\text { 1)/ triacylglycerol lipase }\end{array}$ & $1 e-66$ \\
\hline CF807342 & 3.29 (up) & $2.45 \pm 0.20$ & Unclassified & Hypothetical protein & $2 e-18$ \\
\hline Gma.32376 & 3.27 (up) & $2.38 \pm 0.02$ & Transcription factor & $\begin{array}{l}\text { BLH1 (embryo sac } \\
\text { develop arrest 29) }\end{array}$ & $4 e-21$ \\
\hline Gma.27837 & 3.16 (up) & $1.66 \pm 0.05$ & Unclassified & Hypothetical protein & $7 e-29$ \\
\hline Gma.4149 & $3.13($ down $)$ & $0.42 \pm 0.04$ & Unclassified & Unknown & - \\
\hline Gma.19917 & 3.12 (up) & $1.48 \pm 0.02$ & Metabolism & $\begin{array}{l}\text { CTP } \\
\text { synthase/biosynthesis }\end{array}$ & $3 e-54$ \\
\hline Gma.34551 & 3.08 (up) & $1.71 \pm 0.04$ & Signaling & $\begin{array}{l}\text { MARD1 (mediator of } \\
\text { ABA-regulated } \\
\text { Dormancy1) }\end{array}$ & $2 e-20$ \\
\hline Gma.3429 & 3.02 (up) & $2.01 \pm 0.10$ & Metabolism & $\begin{array}{l}\text { 2-oxoisovalerate } \\
\text { dehydrogenase }\end{array}$ & $3 e-54$ \\
\hline Gma.32595 & 5.25 (up) & $1.32 \pm 0.45$ & Stress response & $\begin{array}{l}\text { Glutathione } \\
\text { s-transferase }\end{array}$ & $7 e-111$ \\
\hline Gma.20326 & $3.2($ down $)$ & $-1.44 \pm 0.20$ & Unknown & & - \\
\hline
\end{tabular}

${ }^{\dagger}$ Significance threshold $(P<.01$, Fold change $>=3) ;{ }^{\dagger \dagger}$ from the $12 \mathrm{~h}$ post treatment, ${ }^{\dagger \dagger \dagger}$ from $72 \mathrm{~h}$ post treatment; up: upregulated; down: downregulated; $e$-value: the probability that the match between the gene and its annotation has no biological basis. Fold change: absolute value of the ratio of gene expression under $\mathrm{Al}$ to gene expression of untreated control. SD: standard deviation.

well-characterized $\mathrm{Al}$ tolerance mechanism in a wide range of plant species $[5,8]$. None of the family members of these two genes were detected in the present study which could be due to constitutive expression. In contrast, an $A B C$ transporter, a multidrug resistance glutathione-S-transferaseexporting ATPase (Gma.14080, Table 2), was upregulated 27 -fold at $48 \mathrm{~h}$ post treatment in the present study, which could detoxify xenobiotics by transporting glutathione-Stransferase conjugated toxin to the vacuole from sensitive sites in symplast. The involvement of $A B C$ transporters in $\mathrm{Al}$ tolerance mechanism is widely documented $[15,18,30$, 31]. Other Al-induced transporters included heavy metal ion transport proteins (Gma.17184 and Gma.24625), lipid transport proteins (DQ222982 and Gma.17184), carbohydrate transport protein (Gma.11888), and coatomer protein complex subunit 2-protien-a polypeptide complex for membrane trafficking (Gma.1654) (Table 2). Heavy metal transport proteins are either located in plasma membrane or subcellular membranes and detoxify heavy metals by exporting metal-ligand complexes out of the cell or by sequestration or compartmentalization of the complex in the vacuole. The internal detoxification mechanism of $\mathrm{Al}$ involves formation of Al-organic acid complexes and subsequent transport of the complex by transport proteins to leaf vacuoles in $\mathrm{Al}$ hyperaccumulating plants that are adapted to acid soils $[1$,
9, 10, 32]. Similar mechanism might operate in cultivated plants, and the heavy metal binding proteins upregulated here might function in such pathway.

Lipid and sugar transport proteins are among other transporters detected. Lipid transport proteins transport lipids to cell wall for biosynthesis of cutin layers and surface waxes as a defense mechanism against pathogen attack [33]. They are also induced by abiotic stresses including aluminum $[15,33]$. Lipid transport proteins loosen cell wall in a nonhydrolytic mode and enhance cell elongation, a role traditionally attributed to expansins [34]. Aluminum stress inhibits root growth by restricting cell wall extension [1]; hence, there should be a significance to the upregulation of lipid transport proteins under Al stress. Plant sugar transporters have been reported to be induced by pathogen attack and $\mathrm{Al}$ stress $[18,35]$, as is the case in the present study (Gma.11888, Table 2).

3.5.3. Genes Related to Stress Response. Aluminum toxicity has been shown to elicit a wide range of stress-related proteins [19, 20,36,37]. In this study, genes known to be responsive to pathogens, oxidative stress, toxins, or $\mathrm{Al}$ were classified under this category. Several pathogenesis-related proteins including syringolide-induced protein, acidic endochitinase, PR-5, basic secretory protein, pathogenesis related 
TABLE 2: Aluminum regulated genes in soybean genotype PI $41693748 \mathrm{~h}$ post treatment ${ }^{\dagger}$.

\begin{tabular}{|c|c|c|c|c|c|}
\hline Unigene ID & Fold change & Average \pm SD & $\begin{array}{l}\text { Functional } \\
\text { category }\end{array}$ & Annotation & $e$-value \\
\hline Gma.6089 & 226.57 (up) & $6.48 \pm 1.80$ & Unclassified & Unknown & - \\
\hline BM139770 & 176.22 (up) & $5.91 \pm 0.80$ & Unclassified & Unknown & - \\
\hline Gma.2586 & 154.32 (up) & $5.86 \pm 0.94$ & Unclassified & Unknown & - \\
\hline Gma.1654 & 130.42 (up) & $4.69 \pm 0.64$ & Transport & $\begin{array}{l}\text { Coatomer protein complex subunit } \\
2 \text { protein transporter }\end{array}$ & $2 e-51$ \\
\hline Gma.26937 & 115.43 (up) & $5.43 \pm 1.37$ & Unclassified & Unknown & - \\
\hline Gma.35222 & 113.94 (up) & $4.67 \pm 0.56$ & $\begin{array}{l}\text { Stress } \\
\text { response }\end{array}$ & $\begin{array}{l}\text { Syringolide-induced protein } \\
\text { B13-1-9 defense protein }\end{array}$ & $4 e-64$ \\
\hline Gma.24062 & 89.44 (up) & $5.15 \pm 1.37$ & Unclassified & Unknown & - \\
\hline Gma.8048 & 79.07 (up) & $5.03 \pm 0.94$ & Unclassified & Unknown & - \\
\hline Gma.27466 & 72.87 (up) & $4.96 \pm 1.57$ & Unclassified & Unknown & - \\
\hline Gma.12326 & 71.14 (up) & $4.84 \pm 1.90$ & Unclassified & Unknown & - \\
\hline Gma.6948 & 69.75 (up) & $4.69 \pm 1.27$ & Unclassified & Unknown & - \\
\hline BU551397 & 65.63 (up) & $4.37 \pm 0.70$ & Unclassified & Hypothetical protein & $2 e-15$ \\
\hline Gma.2523 & 61.59 (up) & $4.78 \pm 0.96$ & $\begin{array}{l}\text { Stress } \\
\text { response }\end{array}$ & $\begin{array}{l}\text { Secretory protein (R14 protein } \\
\text { soybean-defense protein) }\end{array}$ & $6 e-64$ \\
\hline Gma.35601 & 59.51 (up) & $3.61 \pm 0.43$ & Transport & $\begin{array}{l}\text { Heavy-metal } \\
\text { transport/detoxification }\end{array}$ & $2 e-19$ \\
\hline Gma.6948 & 58.09 (up) & $4.45 \pm 0.98$ & Unclassified & Unknown & - \\
\hline Gma.16246 & 55.90 (up) & $4.27 \pm 0.59$ & Unclassified & BAP2 (BON associated protein 2) & $1 e-15$ \\
\hline Gma.30731 & 54.43 (up) & $4.14 \pm 0.90$ & Unclassified & Unknown & - \\
\hline BI967874 & 53.43 (up) & $4.4 \pm 1.35$ & Unclassified & Unknown & - \\
\hline Gma.4526 & 50.59 (up) & $4.38 \pm 1.02$ & $\begin{array}{l}\text { Transcription } \\
\text { factor }\end{array}$ & Zinc finger (C2H2 family protein) & $7 e-27$ \\
\hline Gma.25191 & 47.41 (up) & $5.06 \pm 1.11$ & Unclassified & Unknown & - \\
\hline Gma.9397 & 47.24 (up) & $4.28 \pm 0.98$ & $\begin{array}{l}\text { Stress } \\
\text { response }\end{array}$ & $\begin{array}{l}\text { Syringolide-induced protein } \\
\text { B13-1-9/defense protein }\end{array}$ & $1 e-53$ \\
\hline Gma.25462 & 46.34 (up) & $4.34 \pm 0.65$ & $\begin{array}{l}\text { Transcription } \\
\text { factor }\end{array}$ & WRKY19 DNA-binding protein 19 & $1 e-62$ \\
\hline BU579058 & 45.35 (up) & $4.44 \pm 1.44$ & Metabolism & $\mathrm{N}$-acetyltransferase activity & $2 e-40$ \\
\hline Gma.28852 & 43.12 (up) & $4.10 \pm 0.58$ & Metabolism & Cytochrome P450 & 0.0 \\
\hline Gma.27514 & 41.91 (up) & $3.91 \pm 0.98$ & $\begin{array}{l}\text { Stress } \\
\text { response }\end{array}$ & $\begin{array}{l}\text { Basic secretory protein/defense } \\
\text { protein }\end{array}$ & $3 e-69$ \\
\hline Gma.23347 & 41.67 (up) & $4.08 \pm 1.79$ & Unclassified & Unknown & - \\
\hline Gma.22079 & 41.46 (up) & $4.34 \pm 0.70$ & $\begin{array}{l}\text { Stress } \\
\text { response }\end{array}$ & Glutathione s-transferase & $5 e-57$ \\
\hline Gma.32994 & 40.77 (up) & $3.71 \pm 0.62$ & $\begin{array}{l}\text { Stress } \\
\text { response }\end{array}$ & $\begin{array}{l}\text { Acidic endochitinase (chitinase } \\
\text { III-A) }\end{array}$ & $7 e-93$ \\
\hline Gma.27743 & 39.93 (up) & $4.14 \pm 0.98$ & Unclassified & Unknown & - \\
\hline Gma.1622 & 39.56 (up) & $3.93 \pm 1.02$ & Unclassified & $\begin{array}{l}\text { Hypothetical protein/ABC } \\
\text { transporter like }\end{array}$ & $8 e-31$ \\
\hline Gma.36756 & 36.68 (up) & $4.27 \pm 1.08$ & $\begin{array}{l}\text { Transcription } \\
\text { factor }\end{array}$ & $\begin{array}{l}\text { WRKY17 protein/transcription } \\
\text { factor }\end{array}$ & $1 e-101$ \\
\hline Gma.5622 & 32.77 (up) & $4.29 \pm 0.75$ & Unclassified & Unknown & - \\
\hline Gma.26204 & 32.06 (up) & $3.82 \pm 0.46$ & Metabolism & Transferase/transferase activity & $2 e-29$ \\
\hline Gma.27239 & 31.70 (up) & $3.83 \pm 1.35$ & Unclassified & Unknown & - \\
\hline Gma.36287 & 31.08 (up) & $4.56 \pm 0.48$ & Metabolism & Carboxylesterase/lipase activity & $3 e-64$ \\
\hline Gma.28246 & 30.45 (up) & $3.54 \pm 0.64$ & Unclassified & Unknown & - \\
\hline Gma.36753 & 30.41 (up) & $4.50 \pm 0.74$ & $\begin{array}{l}\text { Transcription } \\
\text { factor }\end{array}$ & WRKY 30(DNA binding protein & $1 e-104$ \\
\hline
\end{tabular}


Table 2: Continued.

\begin{tabular}{|c|c|c|c|c|c|}
\hline Unigene ID & Fold change & Average \pm SD & $\begin{array}{l}\text { Functional } \\
\text { category }\end{array}$ & Annotation & $e$-value \\
\hline Gma.8565 & 29.01 (up) & $3.45 \pm 0.70$ & Metabolism & $\begin{array}{l}\text { Hydrolase /xyloglucan } \\
\text { endotransglycosylase }\end{array}$ & $5 e-18$ \\
\hline Gma.7861 & 28.48 (up) & $3.48 \pm 1.34$ & Unclassified & Unknown & $5 e-20$ \\
\hline Gma.32790 & 28.00 (up) & $3.63 \pm 0.99$ & $\begin{array}{l}\text { Stress } \\
\text { response }\end{array}$ & $\begin{array}{l}\text { Band } 7 \text { family } \\
\text { protein/hypersensitive inducible } \\
\text { reaction protein } 1\end{array}$ & $3 e-27$ \\
\hline Gma.7697 & 27.48 (down) & $-3.66 \pm 0.81$ & Unclassified & $\begin{array}{l}\text { Hypothetical protein } / 31 \mathrm{kDa} \\
\text { glycoprotein }\end{array}$ & $2 e-137$ \\
\hline Gma.31827 & 27.44 (up) & $4.22 \pm 0.65$ & $\begin{array}{l}\text { Transcription } \\
\text { factor }\end{array}$ & WRKY70/DNA-binding protein 70 & $5 e-87$ \\
\hline Gma.21022 & 27.36 (up) & $4.13 \pm 1.18$ & Unclassified & Unknown & - \\
\hline Gma.28273 & 27.29 (up) & $3.84 \pm 0.87$ & $\begin{array}{l}\text { Transcription } \\
\text { factor }\end{array}$ & $\begin{array}{l}\text { NAC6 /NAC domain protein/apical } \\
\text { elongation plant development } \\
\text { protein }\end{array}$ & $2 e-156$ \\
\hline Gma.35830 & 27.20 (up) & $3.48 \pm 0.77$ & Signaling & $\begin{array}{l}\text { Regulation of gene } \\
\text { silencing/calcium-sensor }\end{array}$ & $\begin{array}{l}9 e< \\
\text { ?bhlt? }> \\
-< \\
\text { ?ehlt? }>33\end{array}$ \\
\hline Gma.8262 & 26.92 (up) & $3.73 \pm 1.33$ & $\begin{array}{l}\text { Stress } \\
\text { response }\end{array}$ & $\begin{array}{l}\text { AGc 2-1(oxidative signal-inducible } \\
\text { kinase }\end{array}$ & $3 e-57$ \\
\hline Gma.14080 & 26.50 (up) & $3.81 \pm 0.80$ & Transport & $\begin{array}{l}\text { Similar to ATMRP3/multidrug } \\
\text { resistance glutathione } \\
\text { s-conjugate-exporting ATPase }\end{array}$ & $8 e-11$ \\
\hline Gma.27371 & 25.99 (up) & $3.78 \pm 1.33$ & Unclassified & Unknown & - \\
\hline BM523736 & 25.34 (up) & $3.76 \pm 0.83$ & Metabolism & Transferase family protein & $1 e-23$ \\
\hline Gma.28330 & 25.32 (up) & $3.84 \pm 1.53$ & Unclassified & Calcium-binding protein & $7 e-23$ \\
\hline Gma.34717 & 24.87 (up) & $3.83 \pm 1.15$ & Unclassified & Unknown & - \\
\hline Gma.26682 & 24.58 (up) & $3.95 \pm 1.15$ & Unclassified & Unknown & - \\
\hline Gma.17184 & 24.42 (up) & $3.77 \pm 0.52$ & Transport & $\begin{array}{l}\text { Glycolipid-binding/transport } \\
\text { protein }\end{array}$ & $2 e-57$ \\
\hline Gma.11888 & 24.39 (up) & $3.19 \pm 0.25$ & Transport & $\begin{array}{l}\text { ATPP2-B10 (pheloem protien2) } \\
\text { carbohydrate binding }\end{array}$ & $6 e-27$ \\
\hline Gma.4222 & 23.57 (up) & $3.14 \pm 0.97$ & Unclassified & Hypothetical protein & $2 e-57$ \\
\hline Gma.26712 & 23.39 (up) & $2.82 \pm 0.18$ & Unclassified & Unknown & - \\
\hline Gma.33327 & 23.16 (up) & $3.56 \pm 0.29$ & $\begin{array}{l}\text { Transcription } \\
\text { factor }\end{array}$ & Transcription factor & $2 e-166$ \\
\hline Gma.17019 & 23.08 (up) & $3.67 \pm 1.54$ & Unclassified & Unknown & - \\
\hline Gma.33178 & 23.07 (up) & $3.81 \pm 1.54$ & Unclassified & $\begin{array}{l}\text { Plastocyanin-like } \\
\text { domain-containing copper ion } \\
\text { binding }\end{array}$ & $3 e-33$ \\
\hline Gma 35364 & 22.81 (up) & $3.55 \pm 0.40$ & $\begin{array}{l}\text { Stress } \\
\text { response }\end{array}$ & $\begin{array}{l}\text { FAD-linked oxidoreductase } \\
\text { 1/carbohydrate-oxidase }\end{array}$ & $1 e-52$ \\
\hline Gma.15839 & $22.63($ down $)$ & $-4.00 \pm 0.36$ & Metabolism & GDSL-motif lipase/hydrolase & $2 e-39$ \\
\hline Gma.6948 & 22.54 (up) & $3.73 \pm 1.24$ & Unclassified & Unknown & - \\
\hline Gma.2821 & 22.36 (up) & $3.40 \pm 0.95$ & $\begin{array}{l}\text { Stress } \\
\text { response }\end{array}$ & PR-5 protein (pathogenesis related) & $4 e-134$ \\
\hline Gma. 8628 & 21.20 (up) & $3.19 \pm 1.11$ & Unclassified & Unknown protein & - \\
\hline BQ473604 & 20.51 (up) & $3.43 \pm 0.83$ & Unclassified & Hypothetical protein & $8 e-46$ \\
\hline Gma.9913 & 20.34 (up) & $3.81 \pm 0.44$ & Unclassified & Unknown protein & - \\
\hline Gma.144 & 20.01 (up) & $3.72 \pm 1.00$ & Transport & Nodulin protein/transport function & 0.0 \\
\hline
\end{tabular}


Table 2: Continued.

\begin{tabular}{|c|c|c|c|c|c|}
\hline Unigene ID & Fold change & Average \pm SD & $\begin{array}{l}\text { Functional } \\
\text { category }\end{array}$ & Annotation & $e$-value \\
\hline Gma.34099 & 19.67 (up) & $2.93 \pm 0.93$ & Unclassified & Hypothetical protein & $2 e-77$ \\
\hline Gma.4305 & 19.63 (up) & $3.82 \pm 0.62$ & $\begin{array}{l}\text { Stress } \\
\text { response }\end{array}$ & Glutathione s-transferase (GST 15) & $7 e-128$ \\
\hline Gma.4336 & 19.56 (up) & $3.16 \pm 0.98$ & Unclassified & Unknown & - \\
\hline Gma.24625 & 19.40 (up) & $3.50 \pm 1.12$ & Transport & $\begin{array}{l}\text { Heavy metal } \\
\text { transport/detoxification }\end{array}$ & $2 e-20$ \\
\hline Gma.7726 & 19.18 (up) & $3.36 \pm 1.22$ & Signalling & $\begin{array}{l}\text { Calcium-binding EF hand family } \\
\text { protein }\end{array}$ & $4 e-25$ \\
\hline Gma.26531 & 18.95 (up) & $3.55 \pm 1.31$ & $\begin{array}{l}\text { Transcription } \\
\text { factor }\end{array}$ & $\begin{array}{l}\text { Zinc finger (C3HC4-type ring } \\
\text { familyn) }\end{array}$ & $2 e-26$ \\
\hline Gma.34717 & 18.94 (up) & $3.46 \pm 1.24$ & Unclassified & Unknown & - \\
\hline BE822282 & 18.64 (up) & $2.87 \pm 0.66$ & Unclassified & Unknown & - \\
\hline Gma.27062 & 18.22 (up) & $2.96 \pm 0.95$ & $\begin{array}{l}\text { Transcription } \\
\text { factor }\end{array}$ & $\begin{array}{l}\text { NAc domain containing protein } 2 \\
\text { plant development/apical } \\
\text { elongation }\end{array}$ & $3 e-103$ \\
\hline Gma.4478 & 18.03 (up) & $3.54 \pm 1.03$ & Unclassified & Hypothetical protein & $2 e-10$ \\
\hline Gma.24807 & 18.01 (up) & $3.09 \pm 0.76$ & Unclassified & Unknown & - \\
\hline BK000119.1 & 17.98 (up) & $3.36 \pm 0.87$ & Cell cycle & $\begin{array}{l}\text { Phytosulfokines } 4 \text { precursor/ } \\
\text { growth factor cell differentiation, } \\
\text { cell proliferation }\end{array}$ & $3 e-19$ \\
\hline Gma.29479 & 17.92 (up) & $3.16 \pm 0.52$ & Unclassified & Unknown & - \\
\hline Gma.10956 & 17.76 (up) & $3.32 \pm 0.74$ & $\begin{array}{l}\text { Stress } \\
\text { response }\end{array}$ & $\begin{array}{l}\text { Similar to pathogenesis-related } \\
\text { protein }(\mathrm{STH}-2)\end{array}$ & $1 e-40$ \\
\hline BI967589 & 17.25 (up) & $3.08 \pm 0.49$ & Unclassified & Unknown & - \\
\hline Gma.17184 & 17.16 (up) & $2.94 \pm 0.11$ & Transport & $\begin{array}{l}\text { Heavy-metal-associated domain } \\
\text { containing protein metal ion } \\
\text { transport }\end{array}$ & $1 e-10$ \\
\hline Gma.24561 & 17.08 (up) & $3.15 \pm 0.31$ & Unclassified & Unknown & - \\
\hline Gma.21739 & 17.05 (up) & $3.33 \pm 0.82$ & Metabolism & $\begin{array}{l}\text { AAA-type ATpase protein/ATpase } \\
\text { activity }\end{array}$ & $5 e-39$ \\
\hline Gma.17184 & 16.89 (up) & $3.27 \pm 0.63$ & Transport & $\begin{array}{l}\text { Glycolipid-binding } \\
\text { protein/glycolipid transport }\end{array}$ & \\
\hline Gma.4366 & 16.62 (up) & $3.29 \pm 1.27$ & Metabolism & $\begin{array}{l}\text { VTc2 (Vitamin C defective 2)/ } \\
\text { L-ascorobic-acid biosynthesis }\end{array}$ & $1 e-36$ \\
\hline Gma.26405 & 15.37 (up) & $3.04 \pm 0.83$ & Unclassified & Unknown & - \\
\hline DQ222982 & 15.09 (up) & $3.42 \pm 1.04$ & Transport & Lipocalin/ fatty acid transport & $2 e-107$ \\
\hline Gma.17929 & 15.05 (up) & $3.12 \pm 0.58$ & Metabolism & Transferase family protein & $8 e-76$ \\
\hline Gma.21512 & 14.99 (up) & $2.71 \pm 0.78$ & Unclassified & Unknown & - \\
\hline BE440732 & 14.85 (up) & $3.48 \pm 0.97$ & Unclassified & Unknown & - \\
\hline Gma.29663 & 14.64 (up) & $2.52 \pm 1.04$ & Unclassified & Unknown & - \\
\hline Gma.31861 & 14.60 (up) & $3.09 \pm 1.07$ & Unclassified & Unknown & - \\
\hline Gma.29655 & 14.52 (up) & $3.00 \pm 0.34$ & Metabolism & $\begin{array}{l}\text { CytochromeP50 subfamily B } \\
\text { polypeptide } 1\end{array}$ & $3 e-58$ \\
\hline Gma.11257 & 14.51 (up) & $2.65 \pm 0.86$ & Unclassified & $\begin{array}{l}\text { Hypothetical protein exo-1, } \\
\text { 3-beta-glucanase precursor }\end{array}$ & $9 e-64$ \\
\hline Gma.26640 & 14.48 (up) & $2.93 \pm 1.18$ & Unclassified & Unknown & - \\
\hline Gma.28243 & 14.18 (up) & $3.28 \pm 0.85$ & Unclassified & Unknown & - \\
\hline CD394418 & 14.12 (up) & $3.08 \pm 1.24$ & Metabolism & $\begin{array}{l}\text { Ribulose-1, 5-bisphosphate } \\
\text { carboxylase }\end{array}$ & $2 e-30$ \\
\hline Gma.1527 & 14.09 (down) & $-2.26 \pm 1.40$ & Metabolism & $\begin{array}{l}\text { Dihydroflavonol reductase } \\
\text { (anthocyanin biosynthesis) }\end{array}$ & 0.0 \\
\hline Gma.25234 & 14.08 (up) & $2.96 \pm 0.18$ & $\begin{array}{l}\text { Transcription } \\
\text { factor }\end{array}$ & WRKY43 protein & $4 e-131$ \\
\hline
\end{tabular}


TABle 2: Continued.

\begin{tabular}{llllll}
\hline Unigene ID & Fold change & Average \pm SD & $\begin{array}{l}\text { Functional } \\
\text { category }\end{array}$ & Annotation & $e$-value \\
\hline Gma.28057 & 13.62 (up) & $2.52 \pm 0.68$ & $\begin{array}{l}\text { Transcription } \\
\text { factor }\end{array}$ & Sali5-4a protein (ADR6) & $\begin{array}{l}\text { Stress } \\
\text { response }\end{array}$ \\
Gma.8480 & 13.58 (up) & $3.20 \pm 0.69$ & Resistance protein LM12 & Unc \\
Gma.28756 & 13.53 (up) & $2.89 \pm 0.53$ & Unclassified & Unknown & - \\
BM177218 & 13.45 (up) & $3.14 \pm 0.45$ & Unclassified & Unknown & - \\
BG551078 & 13.37 (up) & $3.09 \pm 0.42$ & Unclassified & Conserved hypothetical protein \\
Gma.728 & 13.28 (up) & $2.78 \pm 0.99$ & Unclassified & Unknown & - \\
Gma.35332 & 13.23 (up) & $3.45 \pm 0.73$ & Unclassified & Unknown & - \\
Gma.26712 & 13.17 (up) & $3.09 \pm 1.01$ & Unclassified & Unknown & - \\
\hline
\end{tabular}

${ }^{\dagger}$ Significance threshold $(P<.01$, Fold change $>=3)$; up: upregulated, down: downregulated; $e$-value: the probability that the match between the gene and its annotation has no biological basis. Fold change: absolute value of the ratio of gene expression under Al to gene expression of untreated control. SD: standard deviation.

protein STH-2, and proteinase inhibitors were upregulated at $48 \mathrm{~h}$ post $\mathrm{Al}$ treatment (Table 2). The confluence between plant molecular response to aluminum toxicity and pathogen infection likely arises from the fact that both cause oxidative stress. However, the role of pathogenesis-related proteins in $\mathrm{Al}$ tolerance is equivocal. Overexpression of peroxidase and proteinase inhibitor genes in Arabidopsis did not improve Al tolerance for the transformed plants relative to controls [38]. On the other hand, overexpressing pepper basic pathogenesis-related protein 1 gene in tobacco resulted in enhanced tolerance to heavy metal cadmium and pathogen infection [39].

Other Al-upregulated stress-related genes included carbohydrate oxidase, glutathione-S-transferase, and glutathione-based reductase (Tables 1 and 2). Carbohydrate oxidase and cell wall peroxidases have been reported to provide protection against pathogens by generating hydrogen peroxide from carbohydrate substrates in the apoplast [14]. Hydrogen peroxide has antimicrobial property and also acts as signal molecule for defense genes expression. In the case of aluminum, the activity of these enzymes is correlated with plant $\mathrm{Al}$ sensitivity $[40,41]$. Glutathione-S-transferase and glutathione-based reductase are the key enzymes of cellular detoxification and antioxidation system [42]. Glutathione reductase catalyses the conversion of oxidized glutathione to reduced form. Glutathione-S-transferase conjugates toxins and electrophilic compounds to reduced glutathione. The glutathione-conjugated toxin is then exported out of the cell or into the vacuole by the $A B C$ transporter proteins discussed above. The concurrent upregulation of glutathione-based reductase, glutathione-S-transferase, and $A B C$ transporter protein suggests that PI 416937 soybean may guard itself against $\mathrm{Al}$ by extruding $\mathrm{Al}$ out of the cell or by compartmentalization of $\mathrm{Al}$ to the vacuole. Yet there are conflicting evidences with respect to the role of the glutathione defense system in plant $\mathrm{Al}$ tolerance. Overexpression of glutathioneS-transferase in Arabidopsis thaliana has been shown to enhance plant $\mathrm{Al}$ tolerance [38]. On the other hand, Maron et al. [17] found more oxidative stress genes upregulation in $\mathrm{Al}$ sensitive cultivar of maize than in $\mathrm{Al}$ tolerant cultivar and argue that oxidative stress genes upregulation is a symptom of Al toxicity rather than a tolerance mechanism, an assertion that is supported by findings of [43]. In addition, these genes are responsive to several biotic and abiotic stress factors and, therefore, should not be regarded as major Al tolerance genes while partial role is certainly possible.

3.5.4. Genes Related to Cellular Metabolism. Genes involved in catabolic or biosynthesis of various metabolites were differentially expressed. The most interesting ones from Al tolerance perspective are genes for biosynthesis of ascorbic acid and genes encoding cytochrome P450 and endo-xyloglucan transferases/hydrolases. All were upregulated in the present study, and the last two were previously reported to be upregulated in Arabidopsis $[19,20]$ and wheat $[15,16]$ roots under $\mathrm{Al}$ stress. Ascorbic acid is an important component of cellular antioxidation system. Oxidative stress is one aspect of $\mathrm{Al}$ toxicity, and maintenance of cellular ascrobate homeostasis has been reported to be an essential component of plant $\mathrm{Al}$ tolerance [16]. Cytochrome P450 may serve as monooxygenase in the biosynthetic pathways for lignin, defense compounds, hormones, pigments, fatty acids, and signaling molecules or in the detoxification pathway to catalyze the breakdown of numerous endogenous and exogenous toxic compounds [44]. We detected two genes (Gma.28852 upregulated 43-fold and Gma.29655- upregulated 15-fold) which code for cytochrome P450 (Table 2). Gma.28852 encodes protein involved in pathways of ascorbate metabolism, coumarine and phenylpropanoid biosynthesis, and gamma hexachlorohexane degradation. Endoxyloglucan hydrolases are cell wall metabolism enzymes. Members of this family of enzymes have been implicated in $\mathrm{Al}$ tolerance [16, 1820]. There is a causal relationship among endoxyloglucan hydrolases, cell wall composition, and $\mathrm{Al}$ tolerance. $\mathrm{Al}$ induced increases in cell wall pectin and hemicellulose increases plant $\mathrm{Al}$ sensitivity [43]. Pectin and hemicellulose form complexes with $\mathrm{Al}$ resulting in increased cell wall rigidity and reduced cell extension and growth [27, 43, 45]. Endoxyloglucan hydrolases appear to relax the Al-rigidified cell wall presumably by hydrolyzing the Al-sugar complexes. 
3.5.5. Genes Related to Cell Signaling. Perception of stress signal by the cell is the starting point for cascade of events leading to gene expression and change in cell metabolism in response to a stress factor. Aluminum perception and signaling is currently poorly understood. Cell wall-associated receptor kinase (WAK1) was the first $\mathrm{Al}$ signaling gene discovered [46], but there is no evidence that demonstrate, WAK1's major role in Al tolerance [1]. Microarray analyses have shown kinases, phosphates, and EF hand $\mathrm{Ca}^{2+}$ binding proteins as possible components of Al signaling pathway [16, 18]. In the present work, a $\mathrm{Ca}^{2+}$ sensor protein (Gma.35830), calcium-binding EF hand family protein (Gma.7726), oxidative signal kinase (Gma.8262), and a gene for growth factor phytosulfokines precursor (BK0001191) were upregulated $48 \mathrm{~h}$ post Al treatment (Table 2 ). The phytosulfokines growth factor is a novel Al-induced gene, and it is involved in cell proliferation and growth, characteristics that confer $\mathrm{Al}$ tolerance.

\section{Conclusion}

We conducted a transcriptome analysis in Al-tolerant soybean line PI 416937 to identify potential genetic factors underlying $\mathrm{Al}$ tolerance trait. Our results uncovered several genes which might potentially have influence on soybean Al tolerance. Among these, two transcription factors, cell wall metabolism enzymes and a cell proliferation gene are particularly interesting from perspective of the physiological and molecular mechanisms of plant $\mathrm{Al}$ tolerance. The first transcription factor, Cys2His2 zinc finger protein, coregulates molecular response to proton and aluminum toxicities, the major acid soil stress factors [28]. The second transcription activator, ADR6 is an auxin downregulated gene. $\mathrm{Al}$ suppresses auxin biosynthesis and transport in root system which might be one possible mechanism of $\mathrm{Al}$ induced root growth inhibition [18]. Conversely, ADR6 is triggered under $\mathrm{Al}$ stress probably acting in a parallel pathway to auxin to restore root growth under $\mathrm{Al}$ stress. Root cell wall rigidification by $\mathrm{Al}$ binding is one principal mechanism of Al toxicity. Cell wall metabolism enzymes and proteins are induced under $\mathrm{Al}$ stress and may counteract $\mathrm{Al}$ effects on root cell walls. It is increasingly evident that these proteins as well as cell wall pectin and hemicellulose content are important determinants of $\mathrm{Al}$ tolerance in cereals [3, 4, 43]. Evidence from this study also implies that cell wall remodeling enzymes and proteins may play role in soybean Al tolerance. Inhibition of cell division and proliferation is another major mechanism of Al toxicity. We identified a novel cell proliferation stimulating gene phytosulfokines growth factor which might reverse this effect of Al. Taken together; our findings provide important insights into the molecular mechanisms of aluminum tolerance in soybean. The genes we identified may guide efforts to improve plant Al tolerance trait.

\section{Acknowledgments}

The authors are grateful to USDA Plant Genetic Resources and Dr. Thomas Carter of North Carolina State University for generous gifts of the seed of soybean genotype used in this study. They thank Dr. Ernst Cebert of Alabama A\&M University for his kind assistance in seed multiplication. They would like to express their appreciation to Dr. Michael Crowley, Genomic core facility at University of Alabama at Birmingham for his assistance and training on microarray hybridization in this project. This research was supported in part by NSF/EPSCOR Grant No. 05026. They are also grateful to Alabama Graduate Research Scholars Program for its financial support. Contributed by Agricultural Experiment Station, Alabama A\&M University.

\section{References}

[1] L. V. Kochian, O. A. Hoekenga, and M. A. Piñeros, "How do crop plants tolerate acid soils? Mechanisms of aluminum tolerance and phosphorous efficiency," Annual Review of Plant Biology, vol. 55, pp. 459-493, 2004.

[2] L. V. Kochian, M. A. Piñeros, and O. A. Hoekenga, "The physiology, genetics and molecular biology of plant aluminum resistance and toxicity," Plant and Soil, vol. 274, no. 1-2, pp. 175-195, 2005.

[3] D. Eticha, A. Staß, and W. J. Horst, "Localization of aluminium in the maize root apex: can morin detect cell wall-bound aluminium?" Journal of Experimental Botany, vol. 56, no. 415, pp. 1351-1357, 2005.

[4] Z. A. K. M. Hossain, H. Koyama, and T. Hara, "Growth and cell wall properties of two wheat cultivars differing in their sensitivity to aluminum stress," Journal of Plant Physiology, vol. 163, no. 1, pp. 39-47, 2006.

[5] J. V. Magalhaes, J. Liu, C. T. Guimarães et al., "A gene in the multidrug and toxic compound extrusion (MATE) family confers aluminum tolerance in sorghum," Nature Genetics, vol. 39, no. 9, pp. 1156-1161, 2007.

[6] J. L. Yang, Y.Y. Li, Y. J. Zhang, et al., "Cell wall polysaccharides are specifically involved in the exclusion of aluminum from the rice root apex," Plant Physiology, vol. 146, no. 2, pp. 602-611, 2008.

[7] D. A. Samac and M. Tesfaye, "Plant improvement for tolerance to aluminum in acid soils-a review," Plant Cell, Tissue and Organ Culture, vol. 75, no. 3, pp. 189-207, 2003.

[8] T. Sasaki, Y. Yamamoto, B. Ezaki et al., "A wheat gene encoding an aluminum-activated malate transporter," The Plant Journal, vol. 37, no. 5, pp. 645-653, 2004.

[9] A. Morita, O. Yanagisawa, S. Takatsu, S. Maeda, and S. Hiradate, "Mechanism for the detoxification of aluminum in roots of tea plant (Camellia sinensis (L.) Kuntze)," Phytochemistry, vol. 69, no. 1, pp. 147-153, 2008.

[10] T. Watanabe, M. Osaki, H. Yano, and I. Rao, "Internal mechanisms of plant adaptation to aluminum toxicity and phosphorus starvation in three tropical forages," Journal of Plant Nutrition, vol. 29, no. 7, pp. 1243-1255, 2006.

[11] C. M. Bianchi-Hall, T. E. Carter Jr., M. A. Bailey et al., "Aluminum tolerance associated with quantitative trait loci derived from soybean PI 416937 in hydroponics," Crop Science, vol. 40, no. 2, pp. 538-545, 2000.

[12] H. Nian, Z. Yang, H. Huang, X. Yan, and H. Matsumoto, "Citrate secretion induced by aluminum stress may not be a key mechanism responsible for differential aluminum tolerance of some soybean genotypes," Journal of Plant Nutrition, vol. 27, no. 11, pp. 2047-2066, 2004. 
[13] V. Ermolayev, W. Weschke, and R. Manteuffel, "Comparison of $\mathrm{Al}$-induced gene expression in sensitive and tolerant soybean cultivars," Journal of Experimental Botany, vol. 54, no. 393, pp. 2745-2756, 2003.

[14] M. Ragland and K. M. Soliman, "Two genes induced by Al in soybean roots," Plant Physiology, vol. 114, p. 395, 1997.

[15] P. Guo, G. Bai, B. Carver, R. Li, A. Bernardo, and M. Baum, "Transcriptional analysis between two wheat near-isogenic lines contrasting in aluminum tolerance under aluminum stress," Molecular Genetics and Genomics, vol. 277, no. 1, pp. $1-12,2007$.

[16] M. Houde and A. O. Diallo, "Identification of genes and pathways associated with aluminum stress and tolerance using transcriptome profiling of wheat near-isogenic lines," $B M C$ Genomics, vol. 9, article 400, 2008.

[17] L. G. Maron, M. Kirst, C. Mao, M. J. Milner, M. Menossi, and L. V. Kochian, "Transcriptional profiling of aluminum toxicity and tolerance responses in maize roots," New Phytologist, vol. 179, no. 1, pp. 116-128, 2008.

[18] M. Kumari, G. J. Taylor, and M. K. Deyholos, "Transcriptomic responses to aluminum stress in roots of Arabidopsis thaliana," Molecular Genetics and Genomics, vol. 279, no. 4, pp. 339-357, 2008.

[19] D. Chandran, N. Sharopova, S. Ivashuta, J. S. Gantt, K. A. VandenBosch, and D. A. Samac, "Transcriptome profiling identified novel genes associated with aluminum toxicity, resistance and tolerance in Medicago truncatula," Planta, vol. 228, no. 1, pp. 151-166, 2008.

[20] D. Chandran, N. Sharopova, K. A. Vandenbosch, D. F. Garvin, and D. A. Samac, "Physiological and molecular characterization of aluminum resistance in Medicago truncatula," $B M C$ Plant Biology, vol. 8, article 89, 2008.

[21] I. R. Silva, T. J. Smyth, D. F. Moxley, T. E. Carter, N. S. Allen, and T. W. Rufty, "Aluminum accumulation at nuclei of cells in the root tip. Fluorescence detection using lumogallion and confocal laser scanning microscopy," Plant Physiology, vol. 123, no. 2, pp. 543-552, 2000.

[22] Z. Wu, R. A. Irizarry, R. Gentleman, F. M. Murillo, and F. Spencer, "A model-based background adjustment for oligonucleotide expression arrays," Journal of the American Statistical Association, vol. 99, no. 468, pp. 909-917, 2004.

[23] M. W. Pfaffl, "A new mathematical model for relative quantification in real-time RT-PCR," Nucleic Acids Research, vol. 29, no. 9, article e45, 2001.

[24] T. L. Maguire, S. Grimmond, A. Forrest, I. Iturbe-Ormaetxe, K. Meksem, and P. Gresshoff, "Tissue-specific gene expression in soybean (Glycine max) detected by cDNA microarray analysis," Journal of Plant Physiology, vol. 159, no. 12, pp. 1361-1374, 2002.

[25] Z. Wu, K. M. Soliman, J. J. Bolton, S. Saha, and J. N. Jenkins, "Identification of differentially expressed genes associated with cotton fiber development in a chromosomal substitution line (CS-B22sh)," Functional and Integrative Genomics, vol. 8, no. 2, pp. 165-174, 2008.

[26] J. S. Morey, J. C. Ryan, and F. M. Van Dolah, "Microarray validation: factors influencing correlation between oligonucleotide microarrays and real-time PCR," Biological Procedures Online, vol. 8, no. 1, pp. 175-193, 2006.

[27] J. Zhang, Z. He, H. Tian, G. Zhu, and X. Peng, "Identification of aluminium-responsive genes in rice cultivars with different aluminium sensitivities," Journal of Experimental Botany, vol. 58, no. 8, pp. 2269-2278, 2007.
[28] S. Iuchi, H. Koyama, A. Iuchi et al., "Zinc finger protein STOP1 is critical for proton tolerance in Arabidopsis and coregulates a key gene in aluminum tolerance," Proceedings of the National Academy of Sciences of the United States of America, vol. 104, no. 23, pp. 9900-9905, 2007.

[29] I. R. Silva, T. J. Smyth, C. D. Raper, T. E. Carter, and T. W. Rufty, "Differential aluminum tolerance in soybean: an evaluation of the role of organic acids," Physiologia Plantarum, vol. 112, no. 2, pp. 200-210, 2001.

[30] P. B. Larsen, M. J. B. Geisler, C. A. Jones, K. M. Williams, and J. D. Cancel, "ALS3 encodes a phloem-localized ABC transporter-like protein that is required for aluminum tolerance in Arabidopsis," The Plant Journal, vol. 41, no. 3, pp. 353363, 2005.

[31] T. Sasaki, B. Ezaki, and H. Matsumoto, "A gene encoding multidrug resistance (mdr)-like protein is induced by aluminum and inhibitors of calcium flux in wheat," Plant and Cell Physiology, vol. 43, no. 2, pp. 177-185, 2002.

[32] J. F. Ma, P. R. Ryan, and E. Delhaize, "Aluminium tolerance in plants and the complexing role of organic acids," Trends in Plant Science, vol. 6, no. 6, pp. 273-278, 2001.

[33] J.-C. Kader, "Lipid-transfer proteins: a puzzling family of plant proteins," Trends in Plant Science, vol. 2, no. 2, pp. 66-70, 1997.

[34] J. Nieuwland, R. Feron, B. A. H. Huisman et al., "Lipid transfer proteins enhance cell wall extension in tobacco," The Plant Cell, vol. 17, no. 7, pp. 2009-2019, 2005.

[35] L. E. Williams, R. Lemoine, and N. Sauer, "Sugar transporters in higher plants - a diversity of roles and complex regulation," Trends in Plant Science, vol. 5, no. 7, pp. 283-290, 2000.

[36] M. A. R. Milla, E. D. Butler, A. R. Huete, C. F. Wilson, O. Anderson, and J. P. Gustafson, "Expressed sequence tag-based gene expression analysis under aluminum stress in rye," Plant Physiology, vol. 130, no. 4, pp. 1706-1716, 2002.

[37] K. D. Richards, E. J. Schott, Y. K. Sharma, K. R. Davis, and R. C. Gardner, "Aluminum induces oxidative stress genes in Arabidopsis thaliana," Plant Physiology, vol. 116, no. 1, pp. 409-418, 1998.

[38] B. Ezaki, R. C. Gardner, Y. Ezaki, and H. Matsumoto, "Expression of aluminum-induced genes in transgenic Arabidopsis plants can ameliorate aluminum stress and/or oxidative stress," Plant Physiology, vol. 122, no. 3, pp. 657-665, 2000.

[39] S. Sarowar, Y. J. Kim, E. N. Kim, et al., "Over expression of a pepper basic pathogenesis-related protein 1 gene in tobacco plants enhances resistance to heavy metal and pathogen stresses," Plant Cell Reporter, vol. 24, pp. 216-224, 2005.

[40] P. R. S. Boscolo, M. Menossi, and R. A. Jorge, "Aluminuminduced oxidative stress in maize," Phytochemistry, vol. 62, no. 2, pp. 181-189, 2003.

[41] G. Delisle, M. Champoux, and M. Houde, "Characterization of oxalate oxidase and cell death in Al-sensitive and tolerant wheat roots," Plant and Cell Physiology, vol. 42, no. 3, pp. 324$333,2001$.

[42] S. Saka, W. Aouacheri, and C. Abdennour, "The capacity of glutathione reductase in cell protection from the toxic effect of heated oils," Biochimie, vol. 84, no. 7, pp. 661-665, 2002.

[43] Q. Liu, J. L. Yang, L. S. He, Y. Y. Li, and S. J. Zheng, "Effect of aluminum on cell wall, plasma membrane, antioxidants and root elongation in triticale," Biologia Plantarum, vol. 52, no. 1, pp. 87-92, 2008.

[44] M. A. Schuler and D. Werck-Reichhart, "Functional genomics of P450s," Annual Review of Plant Biology, vol. 54, pp. 629-667, 2003. 
[45] C. Mao, K. Yi, and L. Yang, "Identification of aluminumregulated genes by cDNA-AFLP in rice (Oryza sativa L.): aluminum-regulated genes for the metabolism of cell wall components," Journal of Experimental Botany, vol. 55, no. 394, pp. 137-143, 2003.

[46] M. Sivaguru, B. Ezaki, Z.-H. He et al., "Aluminum-induced gene expression and protein localization of a cell wallassociated receptor kinase in Arabidopsis," Plant Physiology, vol. 132, no. 4, pp. 2256-2266, 2003. 

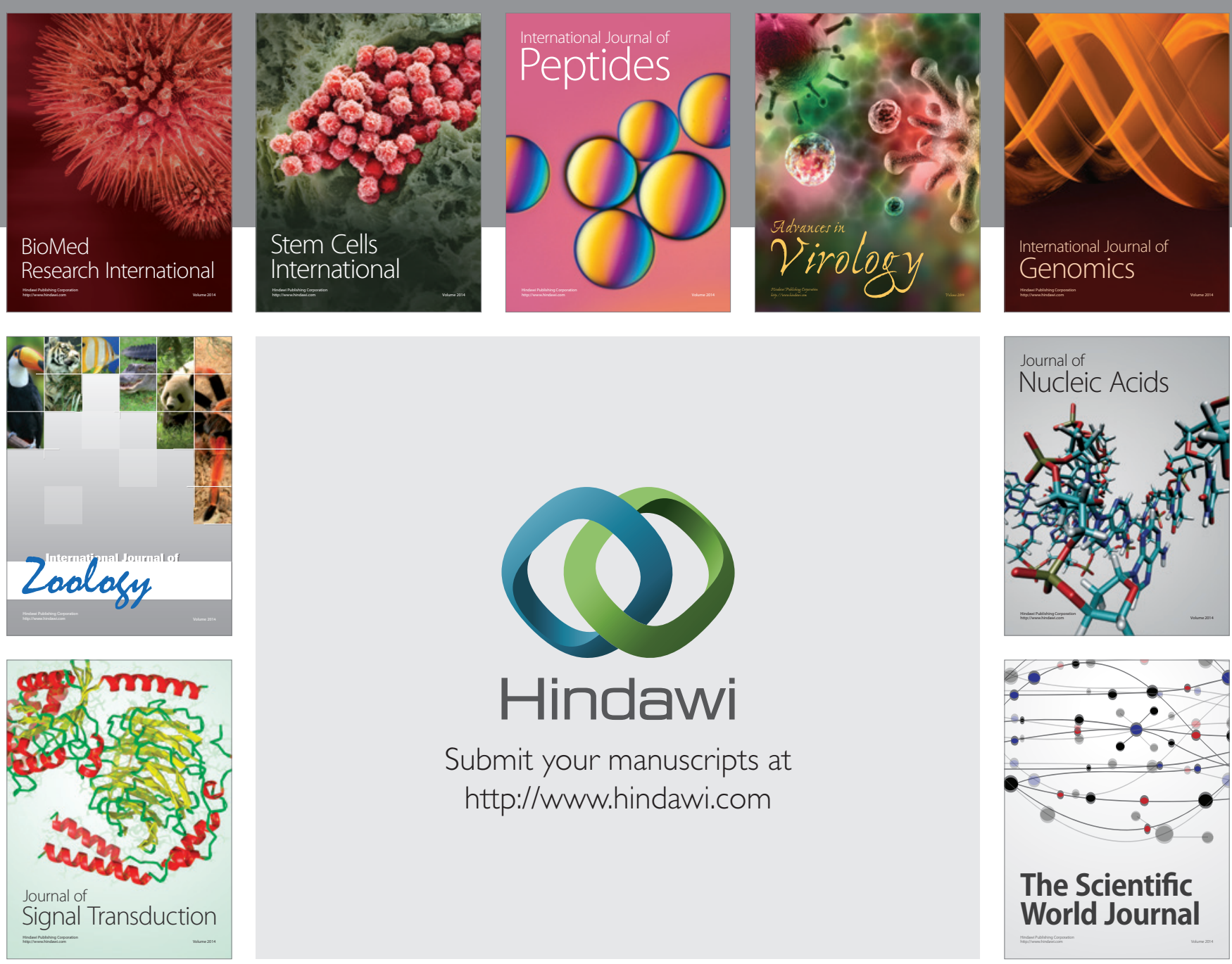

Submit your manuscripts at

http://www.hindawi.com
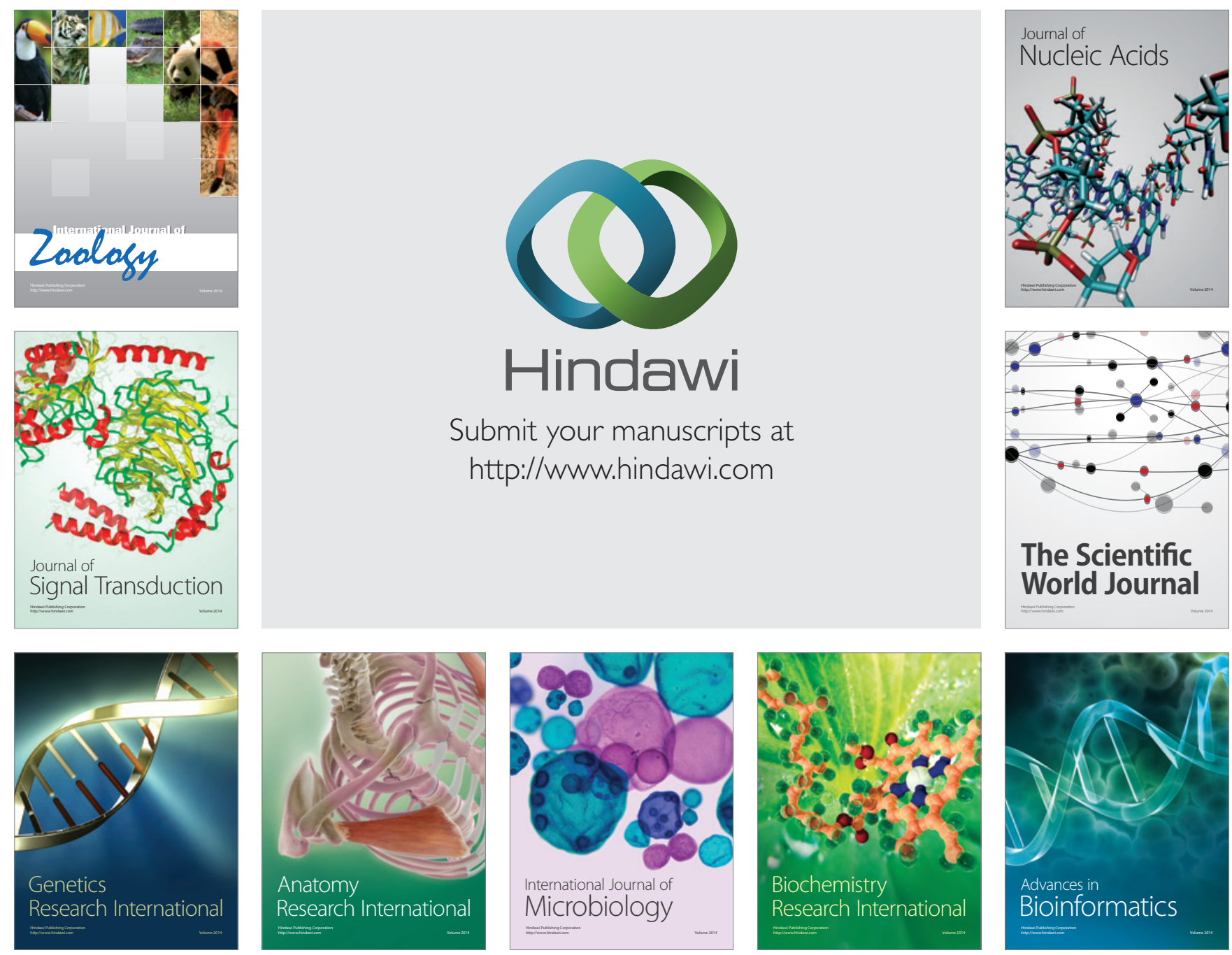

The Scientific World Journal
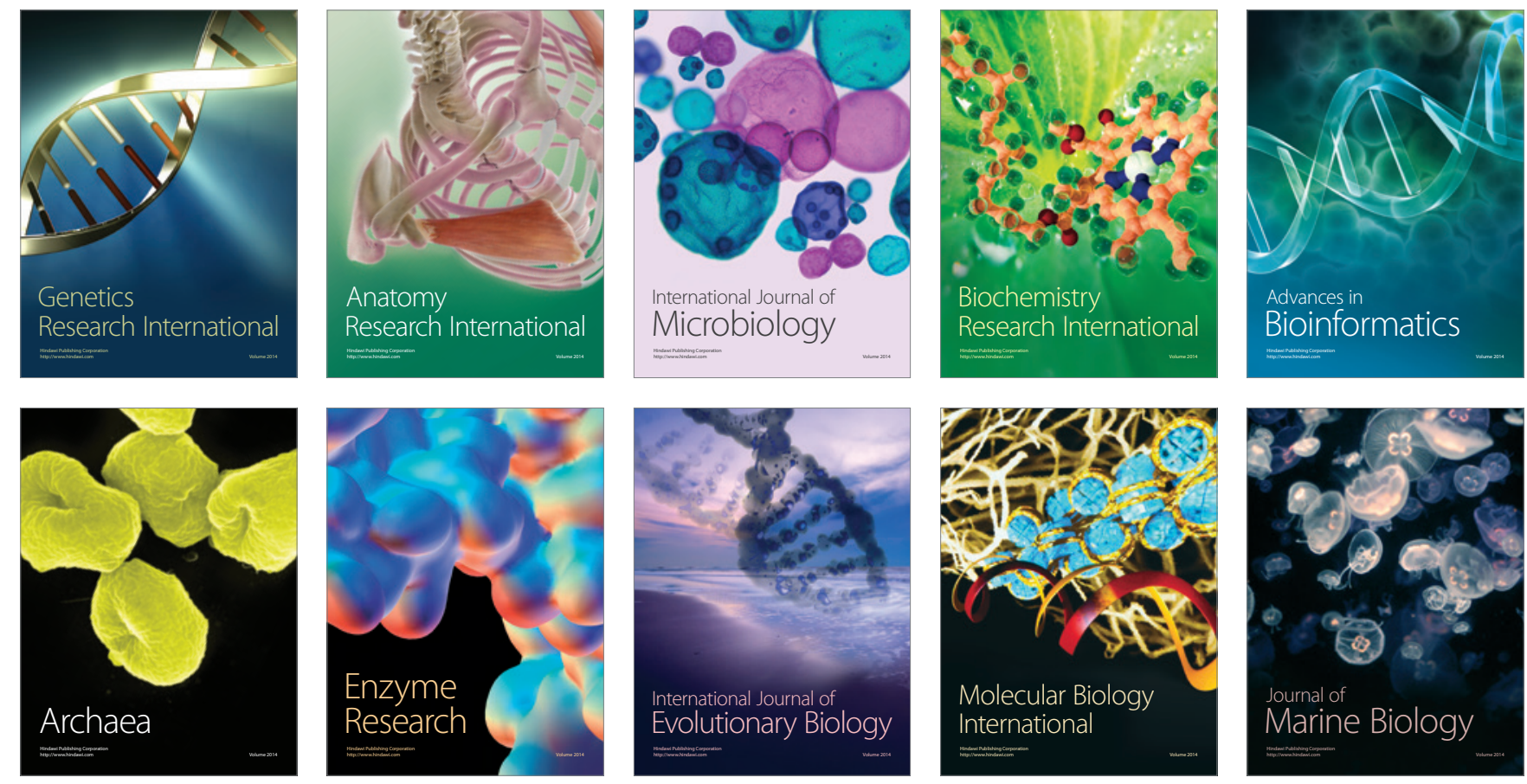